IRA-International Journal of Education \&

Multidisciplinary Studies

QUARTERLY

ISSN 2455-2526; Vol.16, Issue 04 (Oct.-Dec., 2020)

Pg. no. 248-252.

Institute of Research Advances

https://research-advances.org/index.php/IJEMS

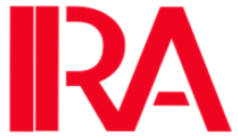

\title{
Power Analysis in The Handmaid's Tale
}

Meijiao Zhao

School of Foreign Studies, University of Science and Technology Beijing, China.

Type of Work: Peer-Reviewed

DOl: http://dx.doi.org/10.21013/jems.v16.n4.p6

\section{How to cite this paper:}

Zhao, M. (2020). Power Analysis in The Handmaid's Tale. IRA International Journal of Education and Multidisciplinary Studies (ISSN 2455-2526), 16(4), 248-252.

DOI: http://dx.doi.org/10.21013/jems.v16.n4.p6

(C) Institute of Research Advances.

This work is licensed under a Creative Commons Attribution-NonCommercial 4.0 International License subject to a proper citation to the publication source of the work.

Disclaimer: The scholarly papers as reviewed and published by the Institute of Research Advances (IRA) are the views and opinions of their respective authors and are not the views or opinions of the IRA. The IRA disclaims of any harm or loss caused due to the published content to any party.

Institute of Research Advances is an institutional publisher member of Publishers International Linking Association Inc. (PILA-CrossRef), USA. The institute is an institutional signatory to the Budapest Open Access Initiative. Hungary advocating the open-access of scientific and scholarly knowledge. The Institute is a registered content provider under Open Access Initiative Protocol for Metadata Harvesting (OAI-PMH).

The journal is indexed \& included in WorldCat Discovery Service (USA), CrossRef Metadata Search (USA), WorldCat (USA), OCLC (USA), Open J-Gate (India), EZB (Germany) Scilit (Switzerland), Airiti (China), Bielefeld Academic Search Engine (BASE) of Bielefeld University, Germany, PKP Index of Simon Fraser University, Canada. 


\begin{abstract}
The Handmaid's Tale is one of Margaret Atwood's most popular novels. As a dystopian novel, it describes an absurd society in the future and explores themes of subjugated women in a patriarchal society and the various means by which these women resist and attempt to gain independence. By applying Michael Foucault's power theory, this paper analyzes the power situations in Gilead, revealing the relationship between power and body, also aims to analyze the relation between female characters' status and power in the novel to reveal the cruelty of the totalitarian government and patriarchal society.
\end{abstract}

Keywords: Power; The Handmaid's Tale; female characters

\title{
Introduction
}

Margaret Atwood is a prolific writer, involved in the feminist movement and human rights movement on the international scene. In 1984, she wrote one of the greatest dystopian novels, The Handmaid's Tale. This novel focuses on a range of important topics, including woman's rights, gender roles, religion, and tyranny. The Handmaid's Tale describes the situation in the late $20^{\text {th }}$ century in the United States. Due to the development of industrial civilization, the environment was destroyed and the children and women were persecuted for serious ecological problems. In the case of extremely low fertility, to solve the problem of infertility, the government uses military power to classify citizens. They are influenced by the Bible. The society of Gilead is dominated by cruel rules. Women in Gilead are deprived of most of their freedom in exchange for protection from predatory men. In particular, handmaids are fertile women forced into sexual servitude to conceive offspring for the elite men known as Commanders. Women have no right to do what they want to do. They must obey the rules and serve Commanders. They are only tools for giving birth to babies for elite families. In such a situation, the conflicts between women and power appear clearly. From this novel, this paper will analyze the power from different aspects and reveal the oppression placed on women.

\section{The Other in Gilead}

The government established a new republic called Gilead, on patriarchal lines, which derives from the Old Testament in the Bible. Women become slaves and homosexuals become "gender traitors"(Atwood, p.189). Homosexuals, old women, and non-white people are sent to the colonies because they are unwanted.

Foucault believes that power is a kind of strategy. First of all, in this novel, the most obvious way of power is categorization/classification. The novel sets in the late $20^{\text {th }}$ century, because of the nuclear leak and chemical contamination, the birth rate has fallen sharply. Based on power, according to the ability to give birth to babies, the government classifies women into different categories. Commanders' Wives, Widows, Aunts, Handmaids, Marthas, Econowives, Jezebels, and Unwoman. Besides, the men also are classified into five categories: commanders, sons of Jacobs, the Eyes (of the Lord), the Angels, the Guardians of the Faith. This kind of categorization has ranked different abilities of women and men. In Gilead, the color represents the government's classification of women. Everyone in Gilead has his or her particular suit color. Men wear black, gray, and dark green clothes, representing their power. While handmaids have to wear red clothes and 
a white hat. "Red" represents "the other" status in Gilead. They are watched and controlled by men. Secondly, the first thing that the ruler of Gilead did is to change the woman's bank account. They were forced to abandon their properties and must rely on male economically. Such measures reflect that women are subordinate to men from social, political, and cultural aspects. One of the main female characters in this book is Commander's wife Serena Joy. She seems to be in the top rank of power and use such power to order handmaids. However, her rights are given by the patriarchal culture. She has to rely on her husband. She has no power in Gilead's government although she used to be an excellent politician. As an accessory to men, Serena's main work is to manage her house and supervise different women in her house. She is forced to accept the "ritual" that the handmaid has sex with Commander every month because she can not bear babies. In addition, there is a group of "aunts", they are responsible for training handmaid's behaviors and habits. Actually, they are the real slaves of the patriarchal society. According to Atwood (2008), they are also victims like handmaids in such a society. They are also "tools" used by the male to train women (p. 19).

A woman who has lost her independence cannot be free in such a society. Although they have a glamorous life, their subordinate status can not be changed. According to Hegel (2016), the contradictory relationship between the self and the other is represented by the relationship between "Master and Slave". "Master" and "Slave" are related. The Master, as the subject, is powerful to the "Slave" who can force him to work. The Slave has no right to resist his Master and has to obey the Master's rules and meet his need (p. 42). In Gilead, "the other" implicits the situation of marginalized, oppressed, and excluded woman's status. According to Beauvoir, woman occupied a secondary role in relation to man, being relegated to the position of the "other". whereas man has been enabled to transcend and control his environment, always furthering the domain of his physical and intellectual conquests, a woman has remained imprisoned within "immanence," remaining a slave within the circle of duties imposed by her maternal and reproductive functions (qtd. in Habib 682). For males, all of the female characters in this novel are "other". In this novel, another problem that reflects a woman's subordinate status is that handmaids don't have their own names. In Gilead, the handmaids have fixed names in different families, like Offred, Ofwarren, Ofglen. The handmaid who went to the same family will use the same name. They are labeled like objects and like Offred said they are just "two-legged wombs, that's all: sacred vessels, ambulatory chalices."(Atwood, 2008, p. 288)

Woman as "the other" in the male-dominated culture is subordinate to males. Beauvoir believes that woman's status was built by history and their identities were negated for such a long time (qtd. in Habib 684). The best way to change their status is to show their particular values and make people hear their voice. The power in the patriarchal society render women marginalized, they are sidelined as "the other" in this imagined country.

\section{The Resistance of Women}

The group of women is the core in this novel and their experiences reflect the hegemonic power in the patriarchal society. According to Atwood's view, women are interesting and important, and they are crucial to the theme, structure and plot of the book. She believes that women are not an afterthought of nature, they are not secondary players in human destiny, without women capable of giving birth, human populations will die 
out. Although her women were oppressed and controlled, they themselves' minds remain inviolable.

On the one hand, handmaids try their best to get rid of Gilead's control. Moira is one of the successful rebels. She resists the new order built by Gilead and her destiny to be a handmaid, so she imprisons an Aunt and got away with the center. She escaped to Canada and started a normal life. "In the light of Moira, the Aunts were less fearsome and more absurd. Their power had a flaw to it. They could be shanghaied in toilets. The audacity was what we liked" (p. 281). Moira gives handmaids hope and courage and makes them know the cruel power can be challenged successfully.

On the other hand, the main character Offred is another kind of rebel. She represents most of the ordinary women in Gilead. She uses different strategies to resist the absurd hegemony. For example, her memory is a kind of resistance. The memory of the former Gilead can remind her desire to overthrow the government and rebuilt the former social structure. She knows her memory is her weapon, "I repeat my former name, remind myself of what I once could do, how others saw me" (p. 203). Her self-awareness helps her live as a person rather than an object in such a society. Offred has strong awareness to insist on her mind. "What I put into them: my own clothes, my own soap, my own money, the money I had earned myself" (p. 51). The words "my own" mean that her subjective consciousness is deeply rooted in her mind. Besides, under the watch of the Eye, Offred communicates with other handmaids through gestures, whispers, signs, and other non-linguistic methods. Their secret communication forms their own language and represents handmaids' rebellious spirit, also reflects their pursuit of subjective consciousness.

Handmaids in Gilead never give up themselves like Foucault states that where there is power, there is resistance (Foucault, 1982, p. 82). No matter how weak the resistance is, it is hidden elements that can threaten the authorities.

\section{Conclusion}

Foucault's theory of power provides us with a perspective to think about power relations. By describing the imagined woman's fate in Gilead, Atwood shows her great concern for her nation as well as the entire society. Although The Handmaids Tale is a novel that imagined future society, its theme is realistic. It describes the persecution of the authoritarian regime against human beings and the killing of human nature, like the situations between World War II. Although the novel was created more than twenty years ago, think about a woman's status nowadays, people should realize the seriousness of the female problems in society.

Power relation is inevitable in a country, it is known that women only have to be closely united and resist the oppression of male power, can they obtain their own voice. In conclusion, through the novel, the writer aims to enlighten the females that suffered from power oppression to fight for their identity bravely. In today's life, the meaning of the novel can be used in the whole world. Facing the unequal things and privileges in today's world, people should use power to protect themselves.

\section{References:}


[1]. Atwood, Margaret. (2017). The Handmaids Tale. London: Vintage Books.

[2]. Foucault, Michel. (1982). The Subject and Power. Sussex: The Harvester Press.

[3]. Foucault, Michel. (1980). Power/knowledge. Sussex: The Harvester Press.

[4]. Habib, M.A.R. (2005). A History of Literary Criticism - From Plato to the Present. Black Publishing.

[5]. Hegel, G.V.F.(2016). The Phenomenology of Mind. Createspace Independent Publishing. 